\title{
The Forest Unseen: A Year's Watch in Nature. By David George Haskell. 2013. Penguin Books, New York. 288 pp.
}

\author{
Steve Wolverton ${ }^{1 *}$ \\ ${ }^{1}$ Department of Geography and the Environment, University of North Texas, USA. \\ *wolverton@unt.edu
}

Received July 27, 2016

OPEN ठACCESS

Accepted August 16, 2016

DOI 10.14237/ebl.7.1.2016.750

Copyright (c) 2016 by the author(s); licensee Society of Ethnobiology. This is an open-access article distributed under the terms of the Creative Commons Attribution-NonCommercial 4.0 International Public License (https://creativecommons.org/licenses/by-nc/4.0), which permits non-commercial use, distribution, and reproduction in any medium, provided the original author and source are credited.

I picked up The Forest Unseen in the spring of 2014 and immediately concluded that it would be a great book for my ethnobiology class. Moreover, it was not just a reading assignment, but it became the model upon which I base much of the course. The book is masterfully written by a truly fascinating biologist who allowed himself to become inductively enthralled by a postage stamp-sized piece of wilderness near his home. The book is premised on the author's observations, in India, of the creation and destruction of a Tibetan Buddhist mandala. He saw the immediate linkage to ecology, that the world is ever-shifting and when we pay attention we witness emergent patterns, which become the basis for tremendously diverse biological and cultural expressions worldwide. Haskell decided to use the mandala as a metaphor, and he constructed his own ecological mandala in the southern Appalachian forest near his home in eastern Tennessee. He determined to visit his square-meter mandala multiple times a month and often many times a week for an entire year. He would sit still and meditatively observe; it was to be participant observation with the local biological world. In the end he fashioned an ethnography of that square-meter mandala, one that is enriching to read and truly beautiful to behold.

The book is laid out chronologically as he traversed the annual cycle. When I use the book in my classes, we cover the periods during which the course takes place. For example, when I teach the course in the spring semester, we read sections from January through May, following along week by week as the seasons change. During his annual journey, Haskell would visit his mandala, key in on something of biological interest, make observations in a journal, return to his home or office, and extensively research what he observed to learn more. The product is a series of reflexive, personal essays that are rich with biological information. What makes the book ethnobiological is that he placed himself as the human in the midst of his square-meter mandala. Truly the book is a lyrical piece that captures this human's interactions with the biota around him. Although Haskell worked from the inspiring template of old growth Appalachian forest, my students and I established our own mandalas on campus, places that we would visit each week and, following Haskell's approach, journal, learn, and reflect upon those places. We published our essays as blog posts, which made it possible for students to share their essays with friends and family members. As this experience was deeply personal, the students were engaged, and their writing was of higher quality than what I am used to encountering in my university classes. Haskell's book is too rich to summarize in great detail; thus, I have chosen three examples - essays or sections thereofthat I found particularly inspiring.

Logged on January $21^{\text {st }}$ of his year's watch in nature, "The Experiment" took place on an exceptionally cold winter day in southern Appalachia. This essay is one that stands out for me because Haskell decided to "experience the cold as the forest's animals do" (p. 12) and thus disrobed down to his undergarments. In the 10 degree Fahrenheit cold Haskell chronicles the acute changes in his physiology, but what I recall most are his observations of Carolina chickadees. After discussing feathers as insulation, he writes (p. 14): 
Shivering is also the chickadees main defense against the cold. Throughout the winter, the birds use their muscles as heat pumps, shivering whenever the birds are cold and the birds are not active. Slabs of flight muscles in the chickadees' chests are the primary sources of heat. Flight muscles account for about a quarter of a bird's body weight, so shivering produces great surges of hot blood. Humans have no comparably huge muscles in our bodies, so our experiences of shivering are weak in comparison.

Haskell (p. 15) recognized his status as a "tropical ape" once he was "stripped of his cultural adaptations" and attempted to invigorate blood flow through five minutes of jumping jacks, but there was a metabolic cost to his activity. The chickadee solves this problem through its sensitive eyesight, which is described in great detail, and that provides the means to detect hidden insects for food. In contrast, Haskell must retreat to his warm kitchen. He confides that he is truly humbled by the chickadee, an "avian master of the cold." My description of this essay is a mere abbreviation, one of the many enjoyable aspects of this book is that Haskell relates small details to grand processes. In this essay, he traverses from personal experiences of the cold, to the physiology of chickadees, to the energy requirements of shivering, to the energetics of body size, and the cold adaptations related to the famous global pattern in animal body size known as Bergmann's Rule.

Haskell maintains clear connections between the particulars of the biological world in his mandala, human experience, and complex systems and processes throughout the book. On April $2^{\text {nd }}$ in the essay entitled "Chainsaw," Haskell wanders away from his mandala to discover the source of the "mechanical whine" of a chainsaw. He determines that the source is a nearby golf course maintenance crew, and is somewhat distraught that the crew is pushing a downed tree over the edge of a cliff into the forest to dispose of it. The tree, he argues however, will provide new habitat for a multitude of lifeforms. Later in the summer, on August $8^{\text {th }}$ Haskell would encounter two golf balls near the edge of his mandala, arrivals from shots gone array. He would struggle with the existential question of whether or not to remove these artifacts. Should he "restore the mandala to "purity" or confront that humans and our material culture are in some distant manner connected to the ecosystems we participate in? Removal would not free the mandala of human impacts from air, water, sound, and even his own presence. He goes deeper (p. 158), again commenting on our status as a "clever primate":

As these able apes get better at controlling their world, they produce some unintended side effects, including strange new chemicals, some of which are poisonous to the rest of life. Most apes have little idea of these ill effects. However, the better-informed ones don't like to be reminded of their species' impact on the rest of the world, especially in places that don't yet seem to be overly damaged. I am such an ape. Therefore, when a golf ball in the woods strikes my eyes, my mind condemns the ball, the golf course, the golfers, and the culture that spawned them all.

In the end, however, humans are part of the biological world, and golf balls "do not end the cycle of matter" (p. 159). Indeed, Haskell asks, who knows the evolutionary potential of golf balls, plastics, and other forms of litter in the long run? He takes us from the lowly golf ball through the biological world to the scale of evolutionary change and geological time, not just putting humans within the biological world but in reference to its processes.

There are over forty essays spanning the seasons in The Forest Unseen, and each ensnares the reader into the world of biology, but each is also ethnobiological, if not directly, then by inference as Haskell references cognition, emotion, and connection willingly. I particularly enjoyed how he describes the biological diversity in flowers, how this relates to evolutionary strategies in pollination, and why this matters in the world. However, my favorite essay is "Eft and Coyote;" there Haskell explores the folklore of wolves, and why they inspire such fear for humans, being symbolized as evil and exterminated in many areas of the world. The eerie howl of the wolf was already fearsome for European colonists when they arrived in the Americas, and wolves were persecuted vigorously. In addition, habitat destruction contributed to the decline in North American wolves. He writes, "fated by their own specialization and by the fear of the colonists, they succumbed as the web was rewoven in the image of northern Europe" (p. 152).

What brought Haskell to this reverie about wolves were the calls of coyotes near his mandala, and his descriptive contrast of the coyote to the specialized 
wolf is my favorite line in the book, "coyotes prefer to dance over the food web rather than perch atop it" (p. 152). Thus, the coyote took advantage of the rewoven tapestry of North America in the centuries after colonization in ways that wolves could not. Eft and Coyote provides gratifying ecological details and thoughtful inquiry well beyond these few quotes, but these types of descriptions are indicative of the lyrical passion that Haskell developed during his year-long watch in nature.

The Forest Unseen is a great read for the layperson with little knowledge of biology; it is also a gratifying read for the trained biologist because Haskell reminds the expert of why we were fascinated by the biological world in the first place. However, I contend that the book is also a thrilling ethnobiological journey within the heart of the United States. This is so because Haskell does not shy away from relating the forms of life and processes he meditates upon with what it means to be human. Any person can experience the outdoors, anywhere in this increasingly urbanized world in the manner that Haskell experienced his mandala. His reflexive essays demystify the sciences of ecology and biology, equating them to human experience. Buy this book, read it, and share it, or better yet create your own mandala and write about it. 